\title{
Evidence provided for the use of oscillating instruments in restorative dentistry: A systematic review
}

\author{
Panagiotis Ntovas ${ }^{1}$, Spyridon Doukoudakis ${ }^{1}$, John Tzoutzas ${ }^{1}$, Panagiotis Lagouvardos ${ }^{1}$
}

Correspondence: Dr. Panagiotis Lagouvardos Email: plagou@dent.uoa.gr
'Department of Operative Dentistry, Dental School, University of Athens, Athens, Greece

\begin{abstract}
Oscillating diamond instruments are considered gentle sources for the removal of demineralized tooth hard tissues and the preparation of cavity angles and margins needed in minimally invasive dentistry. However, there is a question if literature provides enough evidence for their efficacy in restorative dentistry procedures. A literature search until May 2016 was conducted, using PubMed, Scopus, and The Cochrane Central Register of Controlled Trials databases. The quality of the studies was assessed using the recommendation of the Oxford Centre for Evidence-based Medicine. Fifty-five studies were finally included in the study. Of which, $78.2 \%$ of them were laboratory studies and only $21.8 \%$ were clinical studies. The strength of recommendation was 5 for most of them and D their grade of evidence. Bond strength of adhesives on surfaces prepared with these instruments, effective caries removal and cutting characteristics of the oscillating instruments were the main targets of the studies. Conventional diamond, steel, and chemical vapor deposition diamond tips and systems based on abrasive slurry were the oscillating tips, used in different studies. The strength of recommendation and grade of evidence of the studies were low. Although these devices seem to be useful for many clinical situations, there is a need for more well-structured evidence-based studies with more widely accepted procedures and common devices, to have more meaningful results and conclusions of higher strength.
\end{abstract}

Key words: Chemical vapor deposition tips, oscillating instruments, sonic dental devices, sono-abrasion, ultrasonic dental devices, ultrasonic diamond tips

\section{INTRODUCTION}

Oscillating instruments (OIs) belong to the sonic or the ultrasonic type, according to their vibration frequency. ${ }^{[1]}$ OIs were the first utilized in dentistry, in the 1950s, for less invasive tooth structure preparation. ${ }^{[2]}$ Nevertheless, ultrasonic tooth preparation was not universally accepted, due to the limited availability of the tips, poor visibility, and lower efficiency compared to the high-speed rotary handpieces. ${ }^{[3]}$

Gradually, OIs were adapted for the needs of other dental fields, including periodontology, endodontics

\begin{tabular}{|l|l|}
\hline \multicolumn{2}{|c|}{ Access this article online } \\
\hline Quick Response Code: \\
\hline
\end{tabular}

oral and maxillofacial surgery, oral diagnosis, whereas contemporary research investigates its potential for dental tissue repair. ${ }^{[4]}$

The traditional Black's cavity preparation rules passed on the torch to the selective removal of the carious dentin, to preserve sound or potentially remineralizable tissues. ${ }^{[5]}$ Due to the introduction of minimal intervention dentistry, air abrasion and OIs were reconsidered as an alternative to conventional

This is an open access article distributed under the terms of the Creative Commons Attribution-NonCommercial-ShareAlike 3.0 License, which allows others to remix, tweak, and build upon the work non-commercially, as long as the author is credited and the new creations are licensed under the identical terms.

For reprints contact: reprints@medknow.com

How to cite this article: Ntovas $P$, Doukoudakis $S$, Tzoutzas $\mathrm{J}$, Lagouvardos P. Evidence provided for the use of oscillating instruments in restorative dentistry: A systematic review. Eur J Dent 2017;11:268-73.

DOI: 10.4103/ejd.ejd_232_16 
rotary handpieces. ${ }^{[6]}$ Better understanding of the operating conditions, in conjunction with technological developments, led to improved devices, with various tip designs and upgraded diamond coatings, which can be used in many different situations. ${ }^{[7]}$

This article is evidence-based review to summarize and evaluate the existing literature on the use of OIs for the removal of hard tissues in tooth restorations.

\section{MATERIALS AND METHODS}

The review was developed following the guidelines proposed by the PRISMA statement. ${ }^{[8]}$

\section{Eligibility criteria}

We included randomized controlled trials (RCTs), controlled clinical trials, in vitro trials and cases series. Based on the criterion of language, we included articles written in English. Restorative dentistry and hard tissues preparation were all fields of searching. Exclusion criteria included articles that were referred to the use of instruments in other fields of dentistry.

\section{Search strategy}

Studies reporting the use of OIs in enamel and dentin were identified by searching electronic databases. A systematic search of PubMed, Scopus, and The Cochrane Central Register of Controlled Trials from database inception to the end of May 2016 was conducted using the terms "oscillating instruments," "ultrasonic dental devices," "sonic dental devices," "ultrasonic instruments," "hard tissues removal," "ultrasonic caries," "sono-abrasion," and "CVD tips." In addition, we supplemented the search with relative articles of their reference list.

\section{Study selection}

Each article that complied with the predefined eligibility criteria was evaluated by two independent authors individually. Discrepancies, regarding the inclusion of studies, were resolved by discussion and consultation with a third reviewer. The authors used a reference manager software program EndNote X7 to manage reference data. All articles were identified and classified by their title and abstract to inclusion/exclusion criteria. For the next screening level, the complete scientific paper was read.

\section{Data extraction}

Data regarding the study design, sample size, study characteristics, year of publication, type of instrument, and tips were extracted from each included study.

\section{Data analysis}

Included studies were classified according to the Oxford Centre for Evidence-based Medicine levels of evidence classification system ${ }^{[9]}$ [Table 1]. Two reviewers performed the quality assessment of the articles, with one author acting as the coordinator.

\section{Data synthesis}

The narrative synthesis explored the relationship and findings both within and between the included studies and provided an initial descriptive summary and explanation of them. Studies were reported considering their level of evidence. We used the available information generated by in vitro studies, to provide additional evidence to bridge potential gaps between the clinical trials.

\section{RESULTS}

The systematic search revealed 5463 articles. Following the removal of duplicates, as well as their classification, 125 were remained, and their full text assessed against the eligibility criteria by two reviewers. A total of 55 were finally included in the review. The study selection process is shown in Figure 1.

The included studies according to their strength of recommendation, the level of evidence and evaluation objects are presented in Tables 1 and 2 . They were heterogeneous in respect of their design and outcomes. Considering the study design, the majority of studies $43(78.2 \%)$ were laboratory studies, and only 1 study $(1.8 \%)$ was RCT. The level of evidence varied between 1 and 5 . Most of the studies contained a low level of evidence. Studies were performed on human $42(76.4 \%)$, bovine $7(12.7 \%)$, and dog teeth $2(3.7 \%)$.

\begin{tabular}{|c|c|c|}
\hline $\begin{array}{l}\text { Strength of } \\
\text { Recommendation }\end{array}$ & $\begin{array}{l}\text { Level of } \\
\text { Evidence }\end{array}$ & $\begin{array}{l}\text { Diagnosis/Prognosis/ } \\
\text { Treatment }\end{array}$ \\
\hline A & 1 & $\begin{array}{l}\text { Systematic Review of } \\
\text { Randomized Controlled Trial }\end{array}$ \\
\hline \multirow[t]{2}{*}{ B } & 2 & $\begin{array}{l}\text { Systematic Review of } \\
\text { Cohort studies, Randomized } \\
\text { Controlled Trial, Observational } \\
\text { study with dramatic effect, } \\
\text { Inception Cohort Study }\end{array}$ \\
\hline & 3 & $\begin{array}{l}\text { Systematic Review of } \\
\text { Case Control Studies, } \\
\text { Non-Randomized Cohort study }\end{array}$ \\
\hline C & 4 & Case Series, Case Control Studies \\
\hline D & 5 & Bench Research \\
\hline
\end{tabular}

The level of the study may be graded down on the basis of study quality, imprecision, indirectness, because of inconsistency between studies, or because the absolute effect size is very small. Level may be graded up if there is a large or very large effect size 
Ntovas, et al.: Evidence-based review on oscillating instruments

\begin{tabular}{|c|c|c|c|}
\hline Strength of Recommendation & Number of Articles (SoR) & $\%$ & References \\
\hline A & 1 & 1.8 & {$[58]$} \\
\hline B & 3 & 5.4 & {$[51,54,55]$} \\
\hline $\mathrm{C}$ & 8 & 14.6 & {$[9,20,21,23,27,57,59,60]$} \\
\hline $\mathrm{D}$ & 43 & 78.2 & All the rest \\
\hline \multicolumn{4}{|l|}{ Level of Evidence } \\
\hline 1 & 1 & 1.8 & {$[58]$} \\
\hline 2 & 2 & 3.6 & {$[54,59]$} \\
\hline 3 & 2 & 3.6 & {$[51,55]$} \\
\hline 4 & 7 & 12.7 & {$[19,20,21,23,27,57,59]$} \\
\hline 5 & 43 & 78.2 & All the rest \\
\hline \multicolumn{4}{|l|}{ Study object } \\
\hline Bond Strength & $10(D)$ & 18.2 & {$[31,39,41-45,46,47-49]$} \\
\hline Caries removal \& microleakage & $10(D)$ & 18.2 & {$[10,12,24,25,28,29,34,36,46,52]$} \\
\hline Cutting Characteristics & $9(\mathrm{D})$ & 16.4 & {$[11,13,14,26,37,50,61,62,64]$} \\
\hline Response of Dentin-Pulp complex & $5(2 \mathrm{~B}, 1 \mathrm{~A}, 2 \mathrm{D})$ & 9.1 & {$[51,53-55,58]$} \\
\hline Surface Roughness & $4(D)$ & 7.3 & {$[33,36,38,40]$} \\
\hline Smear and Hybrid layer & $3(D)$ & 5.6 & [15-17] \\
\hline Preparation margins & $1(\mathrm{C})$ & 1.8 & [30] \\
\hline Feedback Among Users & $2(\mathrm{C})$ & 3.6 & {$[59,60]$} \\
\hline Other & $11(1 \mathrm{~B}, 6 \mathrm{C}, 4 \mathrm{D})$ & 20.0 & The rest \\
\hline
\end{tabular}

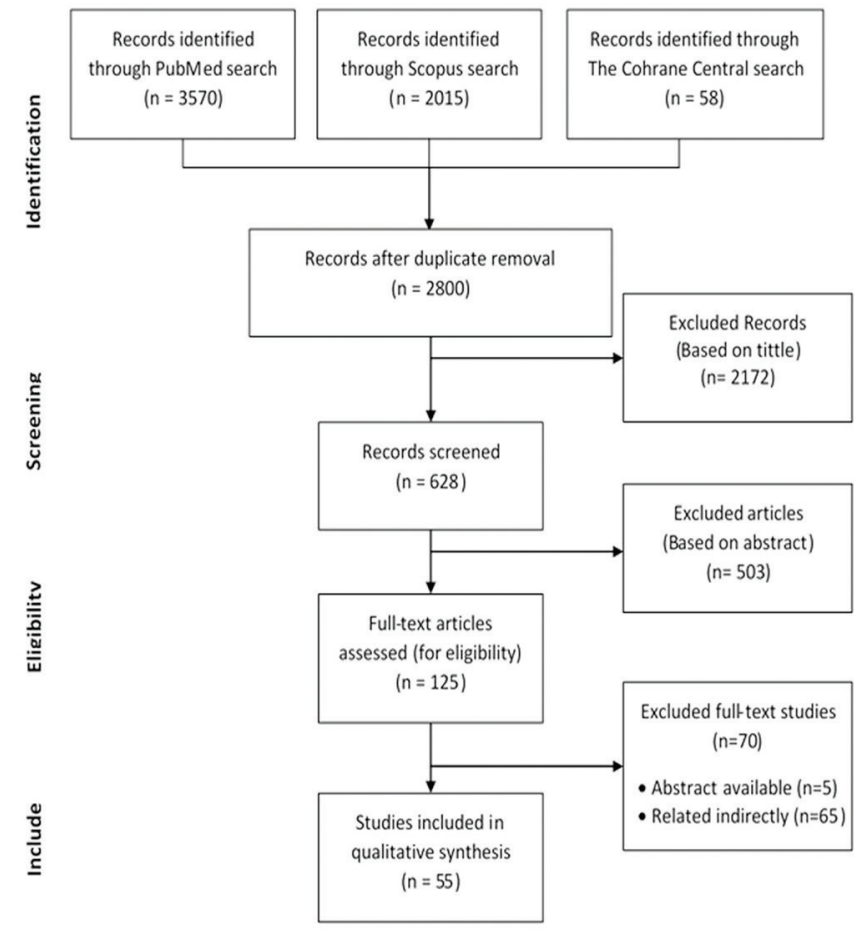

Figure 1: Flowchart of the included studies

Conventional diamond, steel, and chemical vapor deposition (CVD) diamond tips and systems based on abrasive slurry were the oscillating tips, used in different studies.

\section{DISCUSSION}

From a total of 2803 articles initially assessed, only 55 articles were finally scanned and evaluated as fulfilling the inclusion criteria of the study. Articles' "grades of recommendation" were low since more than half of them were bench studies and only a small portion of them was randomized clinical trials which offer the highest level of evidence. Articles also displayed a significant heterogeneity due to differences in employing devices, manner of their use, applied materials and evaluating methods leading to not easily compared conclusions.

One of the first uses of OIs in clinical practice was the preparation of demineralized occlusal pit and fissures. The vibration mode and the angle of the tips in combination with ultra-conservative design, assist the precise and well-controlled removal of carious tissues and/or the implementation of the enameloplasty technique in surfaces with complicated morphology.$^{[10]}$ Although small rotary burs seem to be efficient for precise cutting of small areas, their accuracy is reduced in clinical situations where access is difficult. ${ }^{[10]}$ Etching of the enamel remains of the same importance after preparation either with oscillating or rotary instruments, preparation of occlusal pits and fissures with ultrasonic instruments 
results in the same degree of microleakage, as with the rotary instruments. ${ }^{[11,12]}$ However, the use of ultrasonic instruments for occlusal pit and fissure sealing must be confirmed by further investigation.

OIs present better minimally invasive potential than rotary handpieces since the removal of carious tissues and preparation of sound tissues are selective and well controlled. ${ }^{[11,13,14]}$ Preparation of cavity walls needs attention, as there is a tendency for under preparation. ${ }^{[11,13,14]}$ In deep carious lesions, oscillating diamond instruments are not expected to remove easily the outer soft layer of the lesion and therefore, its use compared to the rotating carbide burs is not promising. In respect to the smear layer present, other studies show that oscillating action seems to completely remove the smear layer, ${ }^{[15]}$ others to remove only an amount of it, ${ }^{[16]}$ and others that the smear layer remains. ${ }^{[17]}$ Further investigation with different tips is needed to confirm these findings because every instrument along with its operation settings can display a variety of cutting profiles with different effect to the dental tissues.

The minimally invasive action of OIs based not only in the selective removal of the dental carious lesion but also in the design which permits the approach of the lesion. Dental caries removal on proximal tooth surfaces constitutes a challenge, due to the massive sacrifice of sound tooth structures, as a result of the traditional restorative procedures. ${ }^{[18]}$ In posterior teeth, OIs can assist the preservation of intact marginal ridges, since special designed tips enable direct approach of proximal lesions or make a tunnel preparation..$^{[19-21]}$ In anterior proximal lesions, the use of OI contributes to the conservative removal of carious tissue preserving sound enamel tissues and consequently natural tooth esthetics. ${ }^{[22,23]}$ The possibility of iatrogenic damage to the adjacent tooth during preparation is minimized. ${ }^{[24]}$

OIs enable the beveling of the inaccessible cervical margins and appear to enhance marginal adaptation. ${ }^{[25,26]}$ The minimally approach and the control of ultrasonic instruments can be further enhanced by microscopy visualization. ${ }^{[27]}$ However, it seems that conventional rotary as well as OIs results in cavities with comparable microleakage values. ${ }^{[24,28,29]}$ The influence of OI on the cervical beveling in respect to microleakage requires clinical research with a bigger variety of oscillating tips and of higher evidence.

The use of OIs has been expanded to the preparation and finishing of the margins for crown and veneer restorations. They produce smooth margins with clear finishing lines which are of the major importance for the precise marginal adaptation of the restorative material and the long-term prognosis of restorations. ${ }^{[30,31]}$ The increased accuracy of the prepared margins to conventional rotary diamond instruments can improve conventional or digital impression and all other stages of the final restoration. ${ }^{[32,33]}$ In addition, the bonded restorations whose cavities prepared with OIs, present lower microleakage than that of rotary diamonds, when the adhesion involves dentin. ${ }^{[34,35]}$ However, caution is important when interpreting such results, since luting agents by themselves can influence significantly the microleakage. ${ }^{[36]}$ The type of ultrasonic tip, the method of application and the preparation protocol are decisive. ${ }^{[37,31]}$

Removal of old composite restorations with OIs sacrifices the same amount of sound tooth tissues as high-speed rotary instruments, but more time is needed to complete the removal. ${ }^{[38]}$ In addition, the roughness that is left on the surface seems to be similar to high-speed rotating instruments using similar grit sizes. ${ }^{[39,40]}$ Oscillating movement is very useful for finishing or repairing restoration's in not easily accessible areas, or when preparation margins are in close contact with soft periodontal tissue that could be damaged by the use of rotary burs. ${ }^{[7,20]}$

Choosing the filling materials for cavities prepared with OIs is important and probably based on the micromorphology characteristics. ${ }^{[7]}$ However, no study was found on the use of different materials for cavities prepared by OIs. It was suggested that when visibility and excavation process is difficult, glass ionomers are preferred due to its cariostatic effect.

Adhesion to the tooth surfaces is affected by the preparation method due to surface quality and bonding medium interaction. ${ }^{[41]}$ In enamel, the OIs seem to affect the adhesion like the conventional rotary instruments. ${ }^{[42]}$ In dentin when self-etch adhesives are involved, surfaces prepared by diamond oscillating tips present similar bond strength to those prepared by steel burs and better than those prepared by diamond burs in high-speed handpieces. ${ }^{[43,44]}$ On the contrary, bond strength seems to be similar or inferior to the surfaces prepared by diamond oscillating tips and diamond rotary burs when two and one step adhesives were used, independently of the adhesive type. ${ }^{[42,45-49]}$ Composite-dentin interface appears to be either the same between the two types of instruments, when Sonicsys tips were used or with a more regular hybrid layer for ultrasonic when CVD tips employed. ${ }^{[50,16]}$ 
In respect to microleakage between composite resin and dentin, one study reports that microleakage was the same with oscillating and rotating instruments and one that diamond burs result in lower microleakage. ${ }^{[51,52]}$ Microleakage must be examined more systematically by clinical trials, in cavities prepared with different OIs, functional parameters, and tips and restored with different adhesive systems to have more conclusive results.

The use of the OI for the preparation of hard dental tissues has been considered from the beginning as a biologically accepted method. ${ }^{[53]}$ Today, clinical data indicate that pulp responses with upgraded oscillating diamond tips appear to be better than high-speed rotary systems. ${ }^{[54]}$ Their acceptance by the patients and especially the children is better, as they reduce the undesirable psychological effects due to low vibration and noise, resulting in less discomfort and pain. ${ }^{[20,55-60]}$ However, contrary to many manufacturers, the use of local anesthesia remains in certain cases necessary. ${ }^{[61]}$

Cost and time are the main drawbacks of using OI. While OIs exist in almost every dental clinic, the cost of diamond tips and their duration limit their use to certain cases only. ${ }^{[40]}$ The increased time for cavity preparation compared to conventional instruments is also a limitation for their use. ${ }^{[61,62,52]}$ Using higher operation power than the recommended, to speed up the cutting effect and reduce the preparation time, can result in an increased cavity size, vibration rate, and noise, leading to patient discomfort. ${ }^{[6,64]} \mathrm{New}$ tips with an enhanced diamond layer, in which a mixture of methane and hydrogen gases form a single artificial layer, improve cutting efficiency. ${ }^{[61]}$

RCTs, case series, and case-control studies and systematic reviews must be made, taking into account, differences in tip design, quality, and the duration of diamond layers on tips and the quality of substance removed or shaped with OIs.

\section{CONCLUSION}

Oscillating diamond instrument constitutes a practical tool, which expands and refines the capabilities of clinical restorative dentistry under the philosophy of minimally invasive dentistry. The knowledge of instruments' tip design along with their indications is necessary requirements to take advantage of their use. There is a need for more well-structured clinical studies with standardized and widely used procedures, devices and materials, to have a high strength of recommendation and grade of evidence conclusions, on the use of OIs in restorative dentistry.

\section{Financial support and sponsorship \\ Nil.}

\section{Conflicts of interest}

There are no conflicts of interest.

\section{REFERENCES}

1. Decup F, Lasfargues JJ. Minimal intervention dentistry II: part 4 . Minimal intervention techniques of preparation and adhesive restorations. The contribution of the sono-abrasive techniques. $\mathrm{Br}$ Dent J 2014;216:393-400.

2. Catuna MC. Sonic energy. A possible dental application. Preliminary report of an ultrasonic cutting method. Ann Dent 1956;12:256-60.

3. Schulein TM. The era of high speed development in dentistry. J Hist Dent 2002;50:131-7.

4. Street EV. A critical evaluation of ultrasonics in dentistry. J Prosthet Dent 1959;9:132-41.

5. Ericson D, Kidd E, McComb D, Mjör I, Noack MJ. Minimally invasive dentistry - Concepts and techniques in cariology. Oral Health Prev Dent 2003;1:59-72.

6. Tyas MJ, Anusavice KJ, Frencken JE, Mount GJ. Minimal intervention dentistry - A review. FDI Commission Project 1-97. Int Dent J 2000;50:1-12.

7. Koubi S, Tassery H. Minimally invasive dentistry using sonic and ultra-sonic devices in ultraconservative class 2 restorations. J Contemp Dent Pract 2008;9:155-65.

8. Moher D, Liberati A, Tetzlaff J, Altman DG. The PRISMA Group preferred reporting items for systematic reviews and meta-analyses: The PRISMA statement. PLoS Med 2009;8:336-41.

9. Oxford Centre for Evidence-Based Medicine. The Oxford Levels of Evidence 2; 2011. Available from: http://www.cebm.net/index. aspx?o $=5653$. [Last retrieved on 2015 Nov 08].

10. Lupi-Pegurier L, Muller-Bolla M, Bertrand MF, Ferrua G, Bolla M. Effect of sono-abrasion in the microleakage of a pit and fissure sealant. Oral Health Prev Dent 2004;2:19-26.

11. Banerjee A, Kidd EA, Watson TF. In vitro evaluation of five alternative methods of carious dentine excavation. Caries Res 2000;34:144-50.

12. Kramer N, García-Godoy F, Lohbauer U, Schneider K, Assmann I, Frankenberger R. Preparation for invasive pit and fissure sealing: Air-abrasion or bur? Am J Dent 2008;21:383-7.

13. Lima LM, Motisuki C, Corat EJ, Santos-Pinto L. Comparative cutting effectiveness of an ultrasonic diamond tip and a high-speed diamond bur. Minerva Stomatol 2009;58:93-8.

14. Neves Ade A, Coutinho E, De Munck J, Van Meerbeek B. Caries-removal effectiveness and minimal-invasiveness potential of caries-excavation techniques: A micro-CT investigation. J Dent 2011;39:154-62.

15. Yazici AR, Ozgünaltay G, Dayangaç B. A scanning electron microscopic study of different caries removal techniques on human dentin. Oper Dent 2002;27:360-6.

16. Oliveira AC, Lima LM, Pizzolitto AC, Santos-Pinto L. Evaluation of the smear layer and hybrid layer in noncarious and carious dentin prepared by air abrasion system and diamond tips. Microsc Res Tech 2010;73:597-605.

17. Banerjee A, Kidd EA, Watson TF. Scanning electron microscopic observations of human dentine after mechanical caries excavation. J Dent 2000;28:179-86.

18. Mount GJ. Minimal intervention dentistry: Rationale of cavity design. Oper Dent 2003;28:92-9.

19. Sheets CG, Paquette JM. Ultrasonic tips for conservative restorative dentistry. Dent Today 2002;21:102-4.

20. Weisrock G, Terrer E, Couderc G, Koubi S, Levallois B, Tassery H, et al. Naturally aesthetic restorations and minimally invasive dentistry. J Minim Interv Dent 2011;4:23-4. 
21. de Vasconcellos BT, Thompson JY, de Paula Macedo MR, de Oliveira Maia JM, Oda M, Garone-Netto N. Ultrasonic cavity preparation using CVD coated diamond bur: A case report. Eur J Dent 2013;7:127-32.

22. Hugo B, Stassinakis A. Preparation and restoration of small interproximal carious lesions with sonic instruments. Pract Periodontics Aesthet Dent 1998;10:353-9.

23. Nahsan FP, Silva LM, Franco EB, Sampaio PC, Francisconi LF, Scaffa PM, et al. Cavity instrumentation with chemical vapor deposition diamond-coated bur. RGO 2012;60:99-103.

24. Opdam NJ, Roeters JJ, van Berghem E, Eijsvogels E, Bronkhorst E. Microleakage and damage to adjacent teeth when finishing Class II adhesive preparations using either a sonic device or bur. Am J Dent 2002;15:317-20.

25. Schmidlin PR, Wolleb K, Imfeld T, Gygax M, Lussi A. Influence of beveling and ultrasound application on marginal adaptation of box-only Class II (slot) resin composite restorations. Oper Dent 2007;32:291-7

26. Giuriato JB, Freitas PN, Dagaze NB, Oda M. In vitro evaluation of microleakage in class $\mathrm{V}$ restorations after cavity preparation with high speed, ultrasonic and laser. Clin Lab Res Dent 2014;20:39-45.

27. Clark D. The operating microscope and ultrasonics; a perfect marriage. Dent Today 2004;23:74-6, 78-81.

28. Rominu M, Florita Z, Rominu O, Sinescu C, Haiduc C, Kigyosi A. Microleakage associated with the use of ceramic inserts. Eur Cells Mater 2006;11:28.

29. Muhammed G, Dayem R. Evaluation of the microleakage of different class V cavities prepared by using Er: YAG laser, ultrasonic device, and conventional rotary instruments with two dentin bonding systems (an in vitro study). Lasers Med Sci 2015;30:969-75.

30. Horne P, Bennani V, Chandler N, Purton D. Ultrasonic margin preparation for fixed prosthodontics: A pilot study. J Esthet Restor Dent 2012;24:201-9.

31. Ellis R, Bennani V, Purton D, Chandler N, Lowe B. The effect of ultrasonic instruments on the quality of preparation margins and bonding to dentin. J Esthet Restor Dent 2012;24:278-85.

32. Ender A, Attin T, Mehl A. In vivo precision of conventional and digital methods of obtaining complete-arch dental impressions. J Prosthet Dent 2016;115:313-20.

33. Solá-Ruiz MF, Faus-Matoses I, Del Rio Highsmith J, Fons-Font A. Study of surface topography, roughness, and microleakage after dental preparation with different instrumentation. Int J Prosthodont 2014;27:530-3.

34. Rominu M, Florita Z, Lakatos S, Rominu RO. Cervical microleakage in class II cavities restored with the Sonicsys approx system. Quintessence Int 2009;40:e7-12.

35. Faus-Matoses I, Solá-Ruiz F. Dental preparation with sonic vs. high-speed finishing: Analysis of microleakage in bonded veneer restorations. J Adhes Dent 2014;16:29-34.

36. Laufer BZ, Pilo R, Cardash HS. Surface roughness of tooth shoulder preparations created by rotary instrumentation, hand planing, and ultrasonic oscillation. J Prosthet Dent 1996;75:4-8.

37. Bittar DG, Murakami C, Hesse D, Imparato JC, Mendes FM. Efficacy of two methods for restorative materials' removal in primary teeth. J Contemp Dent Pract 2011;12:372-8.

38. Geminiani A, Abdel-Azim T, Ercoli C, Feng C, Meirelles L, Massironi D. Influence of oscillating and rotary cutting instruments with electric and turbine handpieces on tooth preparation surfaces. J Prosthet Dent 2014;112:51-8.

39. de Oliveira MT, de Freitas PM, de Paula Eduardo C, Ambrosano GM, Giannini M. Influence of diamond sono-abrasion, air-abrasion and Er: YAG laser irradiation on bonding of different adhesive systems to dentin. Eur J Dent 2007;1:158-66.

40. Scotti N, Bregola A, Chiandussi G, Paolino D, Pasqualini D, Berutti E. Comparative evaluation of the enamel margins roughness obtained with different finishing devices. Minerva Stomatol 2012;61:1-9.

41. Kawaguchi FA, Botta SB, Vieira SN, Júnior SJ, Matos AB. Can surface preparation with CVD diamond tip influence on bonding to dental tissues? Appl Surf Sci 2008;254:4118-22.
42. Takanashi H, Hosaka K, Kishikawa R, Otsuki M, Tagami J. The effect of the dentin preparation with an ultrasonic abrasion on the microtensile bond strength of self-etch adhesive systems. Int Chin Dent J 2010;10:7-15.

43. Souza GS, Souza DB, Santos JL, Klauatu EB, Miranda JE. Influence of rotary diamond and ultrasonic tips on bond strength of composite cingulum rest seats over dentin. Rev Odonto Cienc 2011;26:145-50.

44. Borges $A B$, da Silva MA, Borges AL, Werkman C, Torres CR, Pucci CR. Microshear bond strength of self-etching bonding systems to ultrasound diamond bur-prepared dentin. J Adhes Dent 2011;13:433-8.

45. Cehreli ZC, Yazici AR, Akca T, Ozgünaltay G. A morphological and micro-tensile bond strength evaluation of a single-bottle adhesive to caries-affected human dentine after four different caries removal techniques. J Dent 2003;31:429-35.

46. Pioch T, García-Godoy F, Duschner H, Koch MJ, Staehle HJ, Dörfer CE. Effect of cavity preparation instruments (oscillating or rotating) on the composite-dentin interface in primary teeth. Dent Mater 2003;19:259-63.

47. Cardoso MV, Coutinho E, Ermis RB, Poitevin A, Van Landuyt K, De Munck J, et al. Influence of dentin cavity surface finishing on micro-tensile bond strength of adhesives. Dent Mater 2008;24:492-501.

48. da Silva MA, Di Nicolo R, Barcellos DC, Batista GR, Pucci CR, Rocha Gomes Torres C, et al. Influence of CVD diamond tips and Er: YAG laser irradiation on bonding of different adhesive systems to dentin. J Contemp Dent Pract 2013;14:14-20.

49. Anja B, Walter D, Nicoletta C, Marco F, Pezelj Ribaric S, Ivana M. Influence of air abrasion and sonic technique on microtensile bond strength of one-step self-etch adhesive on human dentin. ScientificWorldJournal 2015;2015:368745.

50. Vieira AS, dos Santos MP, Antunes LA, Primo LG, Maia LC. Preparation time and sealing effect of cavities prepared by an ultrasonic device and a high-speed diamond rotary cutting system. J Oral Sci 2007;49:207-11.

51. Lefkowitz W. Ultrasonics in dentistry. J Am Dent Assoc 1956;52:406-9.

52. Yazici AR, Yildirim Z, Antonson SA, Kilinc E, Koch D, Antonson DE, et al. Comparison of the Er, Cr: YSGG laser with a chemical vapour deposition bur and conventional techniques for cavity preparation: A microleakage study. Lasers Med Sci 2012;27:23-9.

53. Mollica FB, Camargo FP, Zamboni SC, Pereira SM, Teixeira SC, Nogueira L Jr. Pulpal temperature increase with high-speed handpiece, Er: YAG laser and ultrasound tips. J Appl Oral Sci 2008;16:209-13.

54. Monti Lima L, Baffi Diniz M, Aparecida Seccani Galassi M, Toledo De Oliveira Ramalho L, Dos Santos-Pinto L. Evaluation of the dentin-pulp complex after cavity preparation with ultrasonic diamond tip. Minerva Stomatol 2011;60:15-23.

55. Lee MS, Chen YL, Huang PH, Chiang YC, Chang HH, Wu J. Effects of ultrasonic and high-speed air-driven devices on pulp-dentin reactions: An animal study. J Dent Sci 2014;9:359-63.

56. Postle H. Ultrasonic cavity preparation. J Prosthet Dent 1958;8:153-60.

57. Antonio AG, Primo LG, Maia LC. Case report: Ultrasonic cavity preparation - An alternative approach for caries removal in paediatric dentistry. Eur J Paediatr Dent 2005;6:105-8.

58. Chomyszyn-Gajewska M, Kwapinska H, Zarzecka J. Pain perception in children during caries removal with the Vector system: A pilot study. Eur Arch Paediatr Dent 2006;7:38-41.

59. Predebon JC, Flório FM, Basting RT. Use of CVDentUS diamond tips for ultrasound in cavity preparation. J Contemp Dent Pract 2006;7:50-8.

60. Li J, Ge LH, Zhao SY. Evaluation of the use of ultrasonic hand piece and micro-invasive tips in children's dental caries therapy. Beijing Da Xue Xue Bao 2010;42:752-5.

61. Waplington M, Blunt L, Walmsley AD, Lumley PJ. Dental hard tissue cutting characteristics of an ultrasonic drill. Int J Mach Tools Manuf 1955;35:339-43.

62. Wicht MJ, Haak R, Fritz UB, Noack MJ. Primary preparation of class II cavities with oscillating systems. Am J Dent 2002;15:21-5.

63. Josgrilberg EB, Guimarães Mde S, Pansani CA, Cordeiro Rde C. Influence of the power level of an ultra-sonic system on dental cavity preparation. Braz Oral Res 2007;21:362-7.

64. Liao YS, Lee CL, Liao KT. An improved CVDD bur used in ultrasonic dental system for enamel removal. Procedia CIRP 2013;5:231-5. 